\title{
Association of p53 Codon 72 Polymorphism with Breast Cancer in a Rwandese Population
}

\author{
Thierry Habyarimana ${ }^{a-c}$ Mohammed Attaleb ${ }^{a}$ Pacifique Mugenzi ${ }^{d}$ e \\ Jean Baptiste Mazaratic ${ }^{c}$ Youssef Bakri ${ }^{b}$ Mohammed El Mzibri ${ }^{a}$ \\ aBiology and Medical Research Unit, Centre National de I'Energie, des Sciences et des Techniques Nucléaires, \\ Rabat, Morocco; b Department of Biology, Faculty of Science, Mohammed V University, Rabat, Morocco;

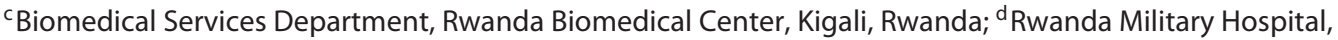

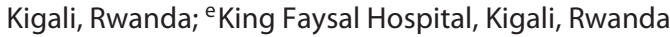

\section{Keywords}

p53 polymorphism - Codon Arg72Pro - Breast cancer .

Rwanda

\section{Abstract}

Background and Aims: A common polymorphism in the tumor suppressor gene $p 53$ at codon 72 has been suggested to play a role in the development of a number of cancers. This polymorphism has been studied in many populations worldwide, with conflicting results. The present study was planned to assess the association of p53 codon 72 polymorphism with breast cancer development in a Rwandese population. Methods: In this study, the polymorphism was examined by allele-specific PCR analysis in 40 patients with breast cancer and 39 healthy controls. Results: The heterozygous genotype Pro/Arg prevailed in both breast cancer patients and controls, and was present in 80\% (32/40) and $92.3 \%$ $(36 / 39)$ of cases, respectively. No statistically significant association was observed between p53 codon 72 polymorphism and breast cancer risk. Distribution of p53 genotypes was also studied according to familial history, tumor grade, and clinical stage, and results clearly showed no statistically significant difference. Conclusion: These results suggest that p53 codon 72 polymorphism could not be assessed as a risk factor marker for predisposition to breast cancer in Rwanda. However, further studies using larger sample sizes are needed to provide more conclusive results and to investigate other genetic mutations affecting the activity of p53.

(c) 2017 S. Karger AG, Basel

\section{Introduction}

The global burden of breast cancer has become an increasing public health problem both in developed and developing countries. In sub-Saharan Africa, breast cancer remains the prevailing malignancy diagnosed in females $[1,2]$. Besides the facts that African women are adopting new lifestyles and undergoing significant demographic transitions, the higher incidence rates of breast cancer may also due to genetic risk factors which are still less studied [3-5].

The human tumor suppressor gene p53 encodes a transcription factor, playing a central role in maintaining cellular integrity by the inhibition of cell growth and

\section{KARGER}

(c) 2017 S. Karger AG, Basel

E-Mail karger@karger.com

www.karger.com/pat
Thierry Habyarimana

Biomedical Services Department, Rwanda Biomedical Center

KN 4 Ave., Indangamirwa, Kiyovu, Nyarugenge

Kigali City, Rwanda

E-Mail thierryestere@yahoo.fr 
Table 1. Characteristics of the study population

\begin{tabular}{lll}
\hline & $\begin{array}{l}\text { Patients } \\
(n=40)\end{array}$ & $\begin{array}{l}\text { Controls } \\
(n=39)\end{array}$ \\
\hline $\begin{array}{l}\text { Age, years } \\
\text { Cancer familial history }\end{array}$ & $40(26-60)$ & $25(18-33)$ \\
$\quad$ Familial cancer & 13 & - \\
$\quad$ Sporadic cases & 27 & - \\
Side & & - \\
$\quad$ Right & 25 & - \\
$\quad$ Left & 15 & - \\
Histological subtypes & & - \\
$\quad$ Invasive ductal carcinoma & 35 & - \\
$\quad$ Unknown & 5 & - \\
Stage & & - \\
$\quad$ II & 13 & - \\
$\quad$ III & 26 & \\
$\quad$ Unknown & 1 & \\
Grade & & \\
$\quad$ I & 2 & - \\
II & 4 & \\
$\quad$ III & 34 & \\
\hline
\end{tabular}

stimulation of apoptosis in response to DNA damage. Its role in cancer development is widely studied and well documented [6]. In human cancer, p53 is frequently mutated and mutations are mainly missense, leading to the expression of full-length mutant p53 protein (mutp53) [6].

The loss of p53 function is often associated with a variety of human tumors including breast cancer. Genetic mutations of $p 53$ contribute to cancer development in different ways: (1) somatic mutations, widely considered as the main mechanism to inactivate p53 and promote cell division; (2) germline Li-Fraumeni mutations associated with predisposition of early-onset cancers including breast carcinomas; and (3) germline p53 polymorphisms in coding and noncoding regions $[7,8]$.

A common single nucleotide polymorphism (SNP) is known in the second position of codon 72 at exon 4 (rs1042522 - CCC to CGC), resulting in a substitution of proline (Pro) to arginine (Arg) in the Pro-rich region [9]. Many studies have reported that the codon 72 polymorphism is associated with a risk for the development of cancer [9-11]. The association of $\mathrm{p} 53$ polymorphism at codon 72 and breast cancer development has been widely studied, but results have been controversial and not conclusive. A number of studies have reported a significant association between the $\mathrm{p} 53$ codon 72 polymorphism and breast cancer risk [12-15], whereas others have identified no such association [16-19].

p53 Codon 72 Polymorphism in Breast Cancer Cases in Rwanda
As the $p 53$ mutations are potential prognostic and predictive markers, as well as targets for therapy $[20,21]$, we planned to evaluate the p53 codon 72 polymorphism in a Rwandese population and to assess the effect of this polymorphism on the risk of breast cancer development in Rwanda.

\section{Materials and Methods}

\section{Study Population}

A total of 40 breast cancer patients and 39 healthy women were enrolled in this study. All breast cancer cases were recruited in 2016 at Rwanda Military Hospital and King Faysal Hospital, both located at Kigali, Rwanda. Characteristics of the breast cancer patients and healthy individuals in the study are described in Table 1. From each breast cancer case, clinical and pathological data (age, tumor localization, histological subtype, clinical stage, and tumor grade) were collected. The protocol study was approved by the Rwanda National Ethics Committee (197/RNEC/2015), and informed consent was obtained from each participant.

\section{Blood Sampling and DNA Extraction}

Approximately $5 \mathrm{ml}$ of whole blood was taken by venipuncture into 5-ml vacutainers (Greiner Bio-One, Germany) containing EDTA. Genomic DNA was isolated from all peripheral blood samples by using a commercial kit (Isolate II Genomic DNA Kit; BIOLINE) according to the manufacturer's recommendations. The DNA obtained was immediately used for polymerase chain reaction (PCR) amplification or stored at $-20^{\circ} \mathrm{C}$ until use.

\section{Genotyping of p53 Gene at Codon 72}

The genotypes of the p53 gene at codon 72 were detected by using allele-specific PCR that specifically detects either the p53 Pro or the p53 Arg allele. The 2 fragments (177 and $141 \mathrm{bp}$, respectively) were amplified in separate reactions with p53 Pro and p53 Arg primers. p53 Pro sequences were detected by PCR using the primer pair p53Pro+/p53- (p53 Pro+: 5' GCCAGAGGCTGCTCCCCC $3^{\prime}$ and p53-: $5^{\prime}$ CGTGCAAGTCACAGACTT $3^{\prime}$ ) and p53 Arg by the primer pair p53+/p53Arg- (p53+: $5^{\prime}$ TCCCCCTTGCCGTCCCAA $3^{\prime}$ and p53 Arg-: 5' CTGGTGCAGGGGCCAC$\left.\mathrm{GC} 3^{\prime}\right)$. Amplification reaction was performed in a total volume of $25 \mu \mathrm{L}$ containing $0.5 \mu \mathrm{M}$ of each consensus primer, 200-mM dNTP, 0.125 units of Taq DNA polymerase, and $2 \mu \mathrm{L}$ of genomic DNA in $1 \times$ Taq polymerase buffer.

DNA was amplified in a GeneAmp PCR System 9700 thermocycler (Applied Biosystems) with the following steps: an initial 10min denaturation at $94^{\circ} \mathrm{C}$ followed by 40 cycles of PCR, with denaturation for $30 \mathrm{~s}$ at $94^{\circ} \mathrm{C}$, primer annealing for $30 \mathrm{~s}$ at $58^{\circ} \mathrm{C}$, and primer extension for $40 \mathrm{~s}$ at $72^{\circ} \mathrm{C}$. At the end of the last cycle, the mixture was incubated for $7 \mathrm{~min}$ at $72^{\circ} \mathrm{C}$ for a final elongation step. Reaction products were analyzed by electrophoresis on a $2 \%$ agarose gel.

\section{Statistical Analysis}

Statistical analyses were performed using XLStat software, the statistical software and data analysis add-on for Excel. Differences were considered statistically significant for $p \leq 0.05$. 
Table 2. Genotypic and allelic frequencies (\%, 95\% CI) in patients and controls

\begin{tabular}{|c|c|c|c|c|c|c|c|c|}
\hline \multirow[t]{2}{*}{ Cases } & \multirow[t]{2}{*}{$n$} & \multicolumn{3}{|l|}{ Genotype } & \multirow[t]{2}{*}{$p$} & \multicolumn{2}{|l|}{ Allele } & \multirow[t]{2}{*}{$p$} \\
\hline & & Pro/Pro & Pro/Arg & Arg/Arg & & Pro & Arg & \\
\hline Breast cancer & 40 & $15(7.1-29.1)$ & $80(65.2-89.5)$ & $5(1.4-16.5)$ & 0.99 & $55(44.1-65.4)$ & $45(34.6-55.9)$ & 0.839 \\
\hline Controls & 39 & $7.7(2.7-20.3)$ & $92.3(79.7-97.3)$ & $0(0-9.0)$ & & $53.8(42.9-64.5)$ & $46.2(35.5-57.1)$ & \\
\hline
\end{tabular}

Table 3. Distribution of $\mathrm{p} 53$ genotype ( $\%, 95 \% \mathrm{CI})$ according to familial history of cancer

\begin{tabular}{|c|c|c|c|c|c|c|c|c|}
\hline Cases & $n$ & Pro/Pro & Pro/Arg & Arg/Arg & $p$ & Pro & Arg & $p$ \\
\hline Sporadic cases & 27 & $18.5(8.2-36.7)$ & $77.8(59.2-89.4)$ & $3.7(0.7-18.3)$ & & $57.4(44.2-69.7)$ & $42.6(30.3-55.8)$ & \\
\hline
\end{tabular}

Fig. 1. Analysis of p53 codon 72 polymorphism by PCR using allele specific primers. Arg/Arg, homozygote arginine; Pro/Pro, homozygote proline; Pro/Arg heterozygote; MW, 100-bp ladder.

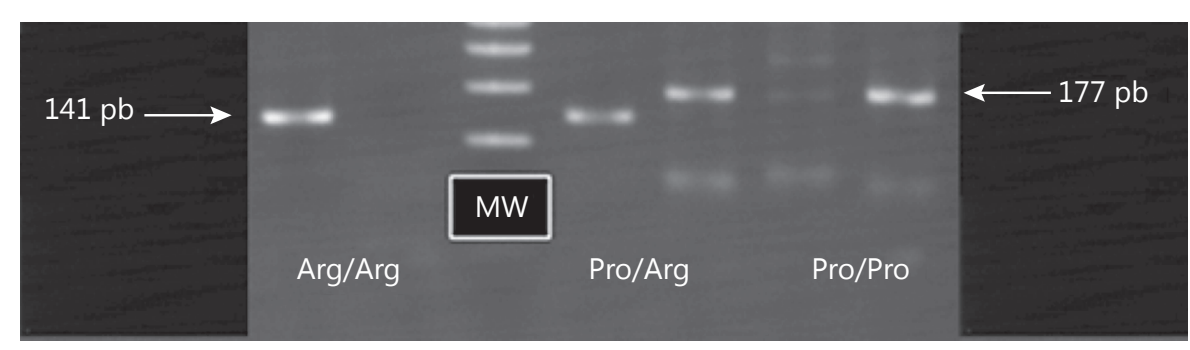

\section{Results}

All samples, 40 cases and 39 controls, were successfully amplified and were analyzed for p 53 codon 72 polymorphic alleles. Results of PCR amplification with Argor Pro-specific primers are reported in Figure 1. Overall, the PCR product analysis showed the presence of the 3 different DNA polymorphisms in the p53 gene: Pro homozygotes, Arg monozygotes, and heterozygous samples.

Table 2 illustrates the genotype distribution of the 3 different biallelic DNA polymorphisms in the $p 53$ gene and corresponding allele frequencies. Overall, the heterozygous genotype prevailed in both breast cancer cases and controls, present in $80 \%(32 / 40)$ and $92.3 \%$ (36/39), respectively. The Arg homozygote genotype was present in only 5 cancer cases and was absent in all control specimens. Genotype distribution in controls and patients was in Hardy-Weinberg equilibrium. There was no significant difference in the overall genotype frequency distribution between the 2 groups.
Distribution of the p53 genotype according to familial history is reported in Table 3 and showed the predominance of the heterozygote genotype in both familial history and sporadic cases. Statistical analysis showed no significant association. The p53 codon 72 polymorphism was also evaluated according to tumor grade and clinical stage. Results are reported in Table 4 and showed no statistically significant difference. The heterozygote genotype Arg/Pro prevailed in all clinical stages and all tumor grades.

\section{Discussion}

During the last decades, great interest has been given to genetic predisposition in cancer development and the use of genetic biomarker for early diagnosis, adequate therapy, and effective monitoring. Predisposition to several human cancers has been associated with genetic polymorphisms, which may represent an important contribution to cancer susceptibility and tumor behavior. 
Table 4. Distribution of p53 genotype (\%,95\% CI) according to clinical stage and tumor grade

\begin{tabular}{|c|c|c|c|c|c|c|c|c|}
\hline Cases & $n$ & Pro/Pro & Pro/Arg & Arg/Arg & $p$ & Pro & Arg & $p$ \\
\hline \multicolumn{9}{|l|}{ Clinical stage } \\
\hline II & 13 & $15.4(4.3-42.2)$ & 76.9 (49.7-91.8) & $7.7(1.4-33.3)$ & \multirow[t]{3}{*}{1.00} & $53.8(35.5-71.2)$ & $46.2(28.8-64.5)$ & \multirow[t]{3}{*}{0.829} \\
\hline III & 26 & $19.2(8.5-37.9)$ & $76.9(57.9-89.0)$ & $3.9(0.7-18.9)$ & & $57.7(44.2-70.1)$ & $42.3(29.9-55.8)$ & \\
\hline Unknown & 1 & - & - & - & & - & - & \\
\hline II & 4 & $0(0-49.0)$ & $75(30.1-95.4)$ & $25(4.6-69.9)$ & \multirow{2}{*}{0.713} & $37.5(13.7-69.4)$ & $62.5(30.6-86.3)$ & \multirow{2}{*}{0.285} \\
\hline III & 34 & $17.6(8.3-33.5$ & $79.4(63.2-89.7)$ & $3(0.5-14.9)$ & & $57.4(45.5-68.4)$ & $42.6(31.6-54.4)$ & \\
\hline
\end{tabular}

The p53 codon 72 polymorphism is the most extensively studied polymorphism in many cancers, including breast cancer. The association between the p53 codon 72 polymorphism and the risk of developing breast cancer has been studied in different populations with conflicting results. To assess the prevalence of p53 SNP72 genotypes and alleles in Rwanda, we have conducted this case-control study on breast cancer patients and paired healthy controls. To our best knowledge, this study is the first investigating the association between $\mathrm{p} 53$ polymorphism in codon 72 and breast cancer development among a Rwandese population.

Overall, the Pro allele is more frequent in the Rwandese population. Both the cancer cases and healthy controls showed a high prevalence of this allele compared to the Arg allele. Brenna et al. [22] have shown that the frequency of the Arg allele increases with latitude, while the Pro allele shows the opposite effect. Moreover, several studies have reported that SNP72 is balanced by natural selection and that the Pro allele frequency increases in a linear manner in multiple populations as they near the equator, with around $60 \%$ in people of African descent and $17-34 \%$ in those of Caucasian descent $[23,24]$.

In this study, the heterozygote genotype (Pro/Arg) prevailed in both cancer cases and controls, and no significant association was obtained for genotype and allele distributions. Our results are in agreement with previously reported data in different populations [25-29]. The meta-analysis conducted by Gonçalves et al. [30] showed that breast cancer patients and control subjects were mainly heterozygous in the Asian population (50.1 and $48.0 \%$, respectively) and the African population (43.9 and $49.7 \%$, respectively), whereas the homozygote Arg/Arg was predominant in America (53.6 and 54.5\%, respectively) and Europe (54.1 and 53.4\%, respectively). How-

p53 Codon 72 Polymorphism in Breast Cancer Cases in Rwanda ever, the Pro/Arg heterozygous genotype was found to be higher in a Saudi population among healthy women $(60.19 \%)$ than in women with breast cancer (25\%) [31], while the Pro/Arg genotype has been reported to be associated with breast cancer risk in an Iranian population, with $75.55 \%$ in breast cancer cases versus $62 \%$ in controls [32]. These discrepancies in frequency distribution could be explained by the genetic specificity of the population and the ethnic group characteristics [33, 34].

When considered separately, sporadic and family cases displayed the same distribution both for genotype and allele frequencies, suggesting no association between this polymorphism and the hereditary form of breast cancer. Conversely, Krivokuca et al. [35] found that in Serbian women the Pro allele is related to hereditary cancer compared to sporadic cancer and could be considered as a potential risk factor for the hereditary form of the disease.

In this study, the distribution of the $\mathrm{p} 53$ codon 72 polymorphism in clinical stages and tumor grades did not show any statistically significant difference. The p53 codon72 genotypes were present with equivalent proportions in all clinical stages and in the reported grades. In this study, out of 34 patients with grade III tumors, $79.4 \%$ had the heterozygous genotype. There are a limited number of studies investigating the association of the p53 codon72 polymorphism with clinicopathological features. In the study conducted in Brazil the homozygous genotype Arg/Arg was more frequent among patients with grade III tumors (17 out of 31 ), but no significant association was observed between tumor grade and genotype [36]. In Finland, Tommiska et al. [19] showed that Pro homozygous breast cancer patients presented significantly more often with grade I tumors, whereas Arg allele carriers had grade III tumors more frequently. The associa- 
tion of Pro homozygosity with lower grade is consistent with a higher frequency of lobular carcinomas among Pro homozygous patients, as lobular carcinomas have been found to be more often of lower grade $[19,37]$. In our study, no lobular carcinoma patient was observed. In breast cancer, the interest was given to mutations affecting the DNA binding domain of p53 and highlighting that these mutations are more prevalent in high-grade and large tumors $[38,39]$.

Many studies have shown that the 2 variants, Pro72 p53 and Arg72 p53, differ in their structure and their biological functions, especially concerning cell cycle progression and apoptotic activity [40,41]. Difference in structure was already reported showing that the Pro72 variant migrates more slowly than the Arg72 variant on gel electrophoresis $[9,33]$. Of particular interest, the Arg72 p53 variant was reported to be more efficient (at least 5 times better) than the Pro72 variant in initiating apoptosis, while the Pro72 variant was reported to be more efficient in inducing cell-cycle arrest [41-43].
In conclusion, these preliminary results suggest no association between p53 codon 72 polymorphism and breast cancer, and therefore this polymorphism could not be assessed as a risk factor marker for predisposition to breast cancer in Rwanda. However, further studies using larger sample sizes are needed to provide more conclusive results and to investigate other genetic mutations affecting the activity of p53.

\section{Acknowledgments}

We thank the Biology and Medical Research Unit, Centre National de l'Energie, des Sciences et des Techniques Nucléaires (CNESTEN), where the work was conducted, and the Rwanda Military Hospital and King Faisal Hospital staff for their collaboration. Special thanks to the study participants.

\section{Disclosure Statement}

The authors declare no conflict of interest.

\section{References}

1 Pace LE, Shulman LN: Breast cancer in subSaharan Africa: challenges and opportunities to reduce mortality. Oncologist 2016;21:1-6.

2 Sylla BS, Wild CP: A million Africans a year dying from cancer by 2030: what can cancer research and control offer to the continent? Int J Cancer 2012;130:245-250.

3 Parkin DM, Nambooze S, Wabwire-Mangen F, Wabinga HR: Changing cancer incidence in Kampala, Uganda, 1991-2006. Int J Cancer 2010;126:1187-1195.

4 Silverstein A, Sood R, Costas-Chavarri A: Breast cancer in Africa: limitations and opportunities for application of genomic medicine. Int J Breast Cancer 2016;2016:1-4.

5 Bray F, Jemal A, Grey N, Ferlay J, Forman D: Global cancer transitions according to the Human Development Index (2008-2030): a population-based study. Lancet Oncol 2012; 13:790-801.

6 Yue X, Zhao Y, Xu Y, Zheng M, Feng Z, Hu W: Mutant p53 in cancer: accumulation, gain-of-function, and therapy. J Mol Biol 2017;429:1595-1606.

7 Olivier M, Hollstein M, Hainaut P: TP53 mutations in human cancers: origins, consequences, and clinical use. Cold Spring Harb Perspect Biol 2010;2:a001008.

8 Sharma S, Sambyal V, Guleria K, Manjari M, Sudan M, Uppal MS, et al: TP53 polymorphisms in sporadic North Indian breast cancer patients. Asian Pacific J Cancer Prev 2014; 15:8413-8422.
9 Matlashewski GJ, Tuck S, Pim D, Lamb P, Schneider J, Crawford LV. Primary structure polymorphism at amino acid residue 72 of human p53. Mol Cell Biol 1987;7:961-963.

10 Storey A, Thomas M, Kalita A, Harwood C, Gardiol D, Mantovani F, et al: Role of a p53 polymorphism in the development of human papillomavirus-associated cancer. Nature 1998;393:229-234.

11 Zhou Y, Li N, Zhuang W, Liu GJ, Wu TX, Yao $\mathrm{X}$, et al: $\mathrm{P} 53$ codon 72 polymorphism and gastric cancer: a meta-analysis of the literature. Int J Cancer 2007;121:1481-1486.

12 Akkiprik M, Sonmez O, Gulluoglu BM, Caglar HB, Kaya H, Demirkalem P, et al: Analysis of p53 gene polymorphisms and protein over-expression in patients with breast cancer. Pathol Oncol Res 2009;15:359-368.

13 Gochhait S, Bukhari SI, Bairwa N, Vadhera S, Darvishi K, Raish $M$, et al: Implication of $B R C A 2-26 \mathrm{G}>\mathrm{A} 5^{\prime}$ untranslated region polymorphism in susceptibility to sporadic breast cancer and its modulation by $p 53$ codon 72 Arg $>$ Pro polymorphism. Breast Cancer Res 2007;9:R71.

14 Sprague BL, Trentham-Dietz A, Garcia-Closas $M$, Newcomb PA, Titus-Ernstoff L, Hampton JM, et al: Genetic variation in TP53 and risk of breast cancer in a populationbased case control study. Carcinogenesis 2007;28:1680-1686.
15 Henríquez-Hernández A, Murias-Rosales LA, Hernández González A, Cabrera De León A, Díaz-Chico B, Mori De Santiago M, et al: Gene polymorphisms in TYMS, MTHFR, p53 and MDR1 as risk factors for breast cancer: a case-control study. Oncol Rep 2009;22:14251433.

16 Baynes C, Healey CS, Pooley KA, Scollen S, Luben RN, Thompson DJ, et al: Common variants in the ATM, BRCA1, BRCA2, CHEK2 and TP53 cancer susceptibility genes are unlikely to increase breast cancer risk. Breast Cancer Res 2007;9:R27.

17 Schmidt MK, Reincke S, Broeks A, Hogervorst FBL, Tollenaar RAEM, Johnson N, et al: Do MDM2 SNP309 and TP53 R72P interact in breast cancer susceptibility? A large pooled series from the Breast Cancer Association Consortium Cancer Association Consortium. Cancer Res 2007;67:9584-9590.

18 Khadang B, Javad M, Talei A, Dehaghani AS, Ghaderi A: Polymorphism of TP53 codon 72 showed no association with breast cancer in Iranian women. Cancer Genet Cytogenet 2007;173:38-42.

19 Tommiska J, Eerola H, Heinonen M, Salonen L, Kaare M, Tallila J, et al: Human cancer biology breast cancer patients with p53 Pro72 homozygous genotype have a poorer survival. Hum Cancer Biol 2005; 11 : 5098-5104. 
20 Chang-Claude J, Ambrosone CB, Lilla C, Kropp S, Helmbold I, von Fournier D, et al: Genetic polymorphisms in DNA repair and damage response genes and late normal tissue complications of radiotherapy for breast cancer. Br J Cancer 2009;100:1680-1686.

21 Petitjean A, Achatz MIW, Borresen-dale AL, Hainaut P, Olivier M: TP53 mutations in human cancers: functional selection and impact on cancer prognosis and outcomes. Oncogene 2007;26:2157-2165.

22 Brenna SM, Guerreiro da Silva ID, Zeferino LC, Pereira J, Martinez EZ, Syrjänen KJ: Prevalence of codon $72 \mathrm{p} 53$ polymorphism in Brazilian women with cervix cancer. Gen Mol Biol 2004;499:496-499.

23 Beckman G, Birgander R, Sjalander A, Saha N, Holmberg PA, KivelaA, et al: Is p53 polymorphism maintained by natural selection. Hum Hered 1994;44:266-270.

24 Leu JD, Wang CY, Tsai HY, Lin IF, Chen RC, Lee YJ: Involvement of p53 R72P polymorphism in the association of MDM2-SNP309 with breast cancer. Oncol Rep 2011;25:17551763.

25 Huang X, Hamajima N, Katsuda N, Matsuo K, Hirose K. Mizutani M, et al: Exon 2 genetic polymorphisms with the risk of Japanese breast cancer. Breast Cancer 2003;10:307311.

26 Zhang Z, Wang $\mathrm{M}$, Wu D, Wang $\mathrm{M}$, Tong $\mathrm{N}$, Tian Y, et al: $P 53$ codon 72 polymorphism contributes to breast cancer risk: a meta-analysis based on 39 case-control studies. Breast Cancer Res Treat 2010;120:509-517.

27 Ohayon T, Gershoni-Baruch R, Papa MZ, Distelman Menachem T, Eisenberg Barzilai S, Friedman E: The R72P P53 mutation is associated with familial breast cancer in Jewish women. Br J Cancer 2005;92:1144-1148.
28 Eltahir HA, Adam AAM, Yahia ZA, Ali NF, Mursi DM, Higazi AM, et al: p53 Codon 72 arginine/proline polymorphism and cancer in Sudan. Mol Biol Rep 2012;39:10833-10836.

29 Chen FM, Ou-Yang F, Yang SF, Tsai EM, Hou MF: P53 codon 72 polymorphism in Taiwanese breast cancer patients. Kaohsiung J Med Sci 2013;29:259-264.

30 Gonçalves M, Borja SM, Cordeiro JA, Saddi VA, Ayres FM, Vilanova-Costa CA, et al: Association of the TP53 codon 72 polymorphism and breast cancer risk: a meta-analysis. Springerplus 2014;3:749.

31 Al-Qasem A, Toulimat M, Tulbah A, Elkum $\mathrm{N}$, Al-Tweigeri T, Aboussekhra A: The p53 codon 72 polymorphism is associated with risk and early onset of breast cancer among Saudi women. Oncol Lett 2012;3:875-878.

32 Boroujeni HR, Karimi M, Moshkelani S, Parsaei P: Association of the p53 codon 72 polymorphism with breast cancer in central part of Iran. African J Pharm Pharmacol 2013;7: 356-359.

33 Thomas M, Kalita A, Labrecque S, Pim D, Banks L, Matlashewski G: Two polymorphic variants of wild-type $\mathrm{p} 53$ differ biochemically and biologically. Mol Cell Biol 1999;19:10921100.

34 Murphy ME: Polymorphic variants in the p53 pathway. Cell Death Differ 2006;13:916-920.

35 Krivokuca AM, Malisic EJ, Dobricic JD, Brotto KV, Cavic MR, Jankovic RN, et al: RAD51 135G > C and TP53 Arg72Pro polymorphisms and susceptibility to breast cancer in Serbian women. Fam Cancer 2014;13:173180
36 Damin AP, Frazzon AP, Damin DC, Roehe A, Hermes V, Zettler C, Alexandre CO: Evidence for an association of TP5 3 codon 72 polymorphism with breast cancer risk. Cancer Detect Prev 2006;30:523-529.

37 Molland JG, Donnellan M, Janu NC, Carmalt HL, Kennedy CW, Gillett DJ: Infiltrating lobular carcinoma - a comparison of diagnosis, management and outcome with infiltrating duct carcinoma. Breast 2004;13:389-396.

38 Kim HW, Lee HM, Hwang SH, Ahn SG, Lee KA, Jeong J: Patterns and biologic features of p53 mutation types in Korean breast cancer patients. J Breast Cancer 2014;17:1-7.

39 Olivier M, Langerod A, Carrier P, Bergh J, Klaar S, Eyfjord S, et al: The clinical value of somatic TP53 gene mutations in 1,794 patients with breast cancer. Clin Cancer Res 2006;12:1157-1167.

40 Schmidt MK, Tommiska J, Broeks A, van Leeuwen FA, Van't Veer LJ, Pharoah PD, et al: Combined effects of single nucleotide polymorphisms TP53 R72P and MDM2 SNP309, and p53 expression on survival of breast cancer patients. Breast Cancer Res 2009;11:R89.

41 Pim D, Banks L: p53 polymorphic variants at codon 72 exert different effects on cell cycle progression. Int J Cancer 2004;108:196-199.

42 Dumont P, Leu JI.-J, Della Pietra AC, George DL, Murphy M: The codon 72 polymorphic variants of p53 have markedly different apoptotic potential. Nat Genet 2003;33:357-365.

43 Zhang L, Shao N, Yu Q, Hua L, Mi Y, Feng N: Association between p53 Pro72Arg polymorphism and prostate cancer risk: a meta-analysis. J Biomed Res 2011;25:25-32. 